\title{
INVESTIGACIÓN
}

\section{Rheological properties of cupuassu and cocoa fats}

\author{
By S. C. S. Lannes, M. L. Medeiros and L.A.Gioielli
}

\begin{abstract}
Biochemical-Pharmaceutical Technology Dept., Pharmaceutical Faculty, São Paulo Univ., Av. Prof. Lineu Prestes, 580/Cidade Univ., São Paulo-SP, CEP 05508-900, Brazil

E-mail: scslan@usp.br
\end{abstract}

\section{RESUMEN}

Propiedades reológicas de las grasas de cupuaçu y del cacao.

La manteca de cacao es un ingrediente muy importante en la formulación de chocolates y es responsable de la mayor parte de sus propiedades (textura, palatibilidad y brillo). En la industria de alimentos, la textura de productos que contienen grasa depende enormemente de las propiedades macroscópicas de la red cristalina de la grasa en el producto final. El cupuaçu es una fruta nativa de la región amazónica y sus semillas pueden ser usadas para obtener una grasa semejante a la manteca de cacao. En general, esta grasa es similar a la manteca de cacao, pero difiere en algunas de sus propiedades fisicas. El objetivo de este estudio fue analizar algunas propiedades de la grasa de cupuaçu y de la manteca de cacao (formación de cristales a $25^{\circ} \mathrm{C}$, propiedades reológicas y composición en ácidos grasos) y de algunas mezclas entre las dos grasas (propiedades reológicas), a fin de conocer el comportamiento de estas grasas para ser usadas en productos de la industria del chocolate. El flujo de la grasa se ha descrito utilizando modelos reológicos comunes (Newton, ley de la potencia, Casson y plástico de Bingham).

PALABRAS-CLAVE: Cupuaçu - Chocolate - Grasa -Reologia.

\section{SUMMARY}

\section{Rheological properties of cupuassu and cocoa fats.}

Cocoa butter is an important ingredient in chocolate formulation as it dictates the main properties (texture, sensation in the mouth, and gloss). In the food industry, the texture of fat-containing products strongly depends on the macroscopic properties of the fat network formed within the finished product. Cupuassu (Theobroma grandiflorum, Sterculiaceae) is an Amazonian native fruit and the seeds can be used to derive a cocoa butter like product. In general, these fats are similar to those of cocoa, although they are different in some physical properties. The objective of this study was to analyze several properties of the cupuassu fat and cocoa butter (crystal formation at $25^{\circ} \mathrm{C}$, rheological properties, and fatty acid composition) and mixtures between the two fats (rheological properties), in order to understand the behavior of these fats for their use in chocolate products. Fat flow was described using common rheological models (Newton, Power Law, Casson and Bingham plastic).

KEY-WORDS: Cupuassu -Chocolate- Fat -Rheology.

\section{INTRODUCTION}

Fats and lipids are employed in food, cosmetics and pharmaceuticals, as main bodies of end products, or as matrices in which cosmetic and pharmacological fine chemicals are dispersed. The molecular species of the fats and lipids are mainly paraffins, fatty acids, glycerols (mono, di and triacyl) and phospholipids.

To control the stability and rheology of foods requires an understanding of the interactions between the various elements present in the system.

Cocoa butter is the only continuous fat phase in chocolate and is therefore responsible for the dispersion of the other constituents. Efforts have been made to find an alternative to cocoa butter and to replace parts of the cocoa butter in chocolate, for economic and technological reasons (Lipp \& Anklam, 1998).

Cupuassu (Theobroma grandiflorum Schumann, Sterculiaceae) is planted for its intensive, characteristic, pleasant taste. This is used to prepare a variety of soft drinks, ice-cream and other desserts. The seeds, which come to about $16 \%$ of the dry weight, can be used to derive a cacao-butter like product; the concentration of fat in the seed is about $50-60 \%$. In general, these fats are similar to those found in cocoa, although they have a different fatty acid profile. The interactions between cocoa and cupuassu fats as well as cupuassu fat alone could be of interest to the confectionery and chocolate industry (Lannes et al., 2000; Vasconcelos, 1975; Venturieri, 1993).

In the food industry, the texture of fat-containing products strongly depends on the macroscopic properties of the fat network formed within the finished product. These properties include the snap of a chocolate bar. The physical state of a fat may vary from a liquid to a viscous fluid to a plastic solid to a brittle solid.

The macroscopic rheological properties of networks formed by lipids are of extreme importance in food products that contain significant amounts of fats. Such products include butter, margarine, chocolate, creams and ice cream. Many of the sensory attributes are dependent on the mechanical strength of the underlying fat crystal network. 
There is no strict dividing line between oil and fat. Oils are liquid at room temperature and fats are solid. In liquid fat, which serves as continuous phase, solid fat crystals are dispersed. Due to the absence of electrostatic or steric repulsion the fat crystals may flocculate and thus be able to form a network. Attraction forces develop after flocculation of the fat crystals, i.e., when the fat crystals are separated by very small distances. Water droplets and air cells are also dispersed in the continuous phase (Rohm \& Weidinger, 1993).

A completely compatible extender should exhibit crystallographic properties equivalent to those of cocoa butter -- alone and as an admixture with cocoa butter. In thermodynamic terms, it should exhibit ideal solid solubility as an admixture with cocoa butter. This requires that the fat molecules be capable of isomorphously replacing cocoa butter molecules in the lattice of the latter, and vice versa (Lannes et al., 2000),

The yield stress of a structured liquid was originally seen as the point at which, when decreasing the applied stress, solid-like behavior was first noticed, i.e. no continual deformation. There is usually a small range of stress over which the mechanical properties change dramatically (an apparent yield stress), these materials neverthless show slow but continual steady deformation when stressed for a long time below this level, having shown an initial linear elastic response to the applied stress. At the lowest stresses, this creep behavior for structured liquids can be described by a Newtonian-plateau viscosity. As the stress is increased the flow behavior usually changes into a power-law dependence of steady-state shear rate on shear stress (Barnes, 1999).

\section{MATERIAL AND METHODS}

\subsection{Material}

Mixtures between cocoa butter (deodorized) from Bahia-Brazil, and cupuassu fat (not treated) from Amazonian-Brazil were made in the following proportions (Table I).

\subsection{Methods}

\subsubsection{Fatty acids composition}

Fatty acid composition was determined after conversion of fatty acids into their corresponding methyl esters by the method described by Hartman \& Lago (1973). Analyses of fatty acid methyl esters were performed on a gas liquid chromatograph Varian GC (São Paulo, Brazil), model 3400CX, equipped with split-injection port, flame-ionization detector, Star Chromatography Workstation and a 30

\begin{tabular}{|c|c|c|}
\multicolumn{3}{|c}{$\begin{array}{c}\text { Table I } \\
\text { Mixtures }\end{array}$} \\
\hline MIXTURES & \multicolumn{2}{|c|}{ PROPORTIONS (\%) } \\
\hline & Cocoa butter & Cupuaçu fat \\
\hline M1 & 10 & 90 \\
M2 & 90 & 10 \\
M3 & 70 & 30 \\
M4 & 30 & 70 \\
M5 & 50 & 50 \\
M6 & 0 & 100 \\
M7 & 100 & 0 \\
\hline
\end{tabular}

$\mathrm{m}$ fused silica capillary column (ID $=0.25 \mathrm{~mm}$ ) coated with $0.25 \mathrm{~m}$ of CP-Wax 52CB (Chrompack). Helium carrier gas flow was $1.5 \mathrm{~mL} / \mathrm{min}$ at a split ratio of $1: 50$. Injector temperature was $250^{\circ} \mathrm{C}$. Detector temperature was $280^{\circ} \mathrm{C}$. The oven temperature initially was set at $150^{\circ} \mathrm{C}$ for $5 \mathrm{~min}$, then programmed at $3^{\circ} \mathrm{C} / \mathrm{min}$ to $215^{\circ} \mathrm{C}$. After drawing up air into the filled syringe (sample volume $1 \mu \mathrm{L}$ ) and inserting the neddle into the heated injector, samples were injected manually after a dwell-time of $2 \mathrm{~s}$. Qualitative fatty acid composition was determined by comparing the retention times of the peaks with the respective standards of fatty acids. Quantitative composition was accomplished by area normalization, expressed as mass percent, according to method Ce 1-62 (AOCS, 1990). Samples were run in duplicate and the values were averaged.

\subsubsection{Rheology}

The rheological parameters were measured using a Rheotest RN 3.1 with thermostatic bath, using a concentric cilinder, at a temperature of $40^{\circ} \mathrm{C}$. The tests were conducted by controlled stress (500 $1 / \mathrm{s})$, for $120 \mathrm{sec}$. The flow was described using rheological models (Newton, Power-Law, Casson and Bingham plastic).

\subsubsection{Polarized light microscopy}

The samples were warmed at 60 to $70^{\circ} \mathrm{C}$ in a microwave oven (Panasonic, São Paulo, Brazil) and then were kept in an oven at $70^{\circ} \mathrm{C}$ for 15 minutes to complete the melting of the crystals. A drop of melted fat was placed on a glass microscope slide, and covered with a cover-slip. The slides, as well as the cover-slips, were pre-heated, prepared at $50^{\circ} \mathrm{C}$, and kept at $25^{\circ} \mathrm{C}$, for 24 hours.

Crystal morphology was studied under isothermal conditions with a polarized light 
microscope (Olympus System Microscope, model BX 50 - Olympus America Inc.) fitted with a digital camera (Media Cybernetics). The objective magnification was $4 \mathrm{x}$, and the ocular magnification was 10x. Temperature was controled with a specially built platen equipped with a heating/cooling system (Thermal Microscope Stage, TS-4 - Physitemp Instruments Inc.). The images show a typical field for each sample. The images were analyzed by the software Image Pro-Plus Version 4.5.1 for Windows (Media Cybernetics). The diameters $(\mu \mathrm{m})$ of the crystals were determined.

\section{RESULTS AND DISCUSSION}

Cocoa butter is the name given to a fatty compound, which is composed of many different lipids, or fats. Some lipids are tri-esters of glycerol, and are known as triacylglycerols. The primary triglycerols present in cocoa butter are a combination of palmitic, stearic, and oleic fatty acids (Lannes \& Gioielli, 1997).

In many fats and lipids, combinations of the fatty acid moieties are heterogeneous, e.g., saturated and unsaturated acids, unsaturated fatty acids with cis-double bonds placed at different positions, short and long chain acids, even and odd carbon-numbered fatty acids, etc. In these specimens, aliphatic chain-chain interactions are critical factors determining their physical properties (Sato, 2001).

In Table II we can observe that the fatty acid composition of cupuassu fat is very similar to cocoa butter. Palmitic acid in cupuassu fat is present in much smaller amounts $(7.8 \%)$ than in cocoa butter $(26.1 \%)$; stearic acid is about the same; oleic acid is higher in cupuassu. Particularly notable is the high amount of arachidic acid (20:0) in cupuassu fat.

Although cupuassu has a higher SOS content than cocoa butter, its contents of POP and POS are much lower reflecting its low level of palmitic acid. Total SOS-type triacylglycerols, i.e. $\mathrm{POP}+\mathrm{POS}+$ SOS+SOA, is $57 \%$ in cupuassu and $83 \%$ in cocoa butter, thus explaining the melting profiles given in Figure 1. Fractionation, as applied to fats such as shea and sal, would be needed to bring the total SOS-type content to the same level as in cocoa butter. Fractionation could be used to modify cupuassu fat to make it more similar to cocoa butter for use as a CBE (cocoa butter equivalent), with $65 \%$ minimum of total SOS-type triacylglycerols (Lannes, 2003).

\section{Rheology}

Below the yield value, fats show elastic properties, but it appears that these are not of great technological importance. Above the yield value, both the yield value magnitude and the plastic
Table II

Fatty acid composition (\%) of cocoa butter and cupuassu fat

\begin{tabular}{|c|cc|}
\hline \multicolumn{3}{|c|}{ FATTY ACID } \\
\hline & Cocoa Butter & Cupuassu fat \\
\hline $\mathbf{C}_{\mathbf{1 4 : 0}}$ & 0.1 & - \\
$\mathbf{C}_{\mathbf{1 6 : 0}}$ & 26.8 & 7.8 \\
$\mathbf{C}_{\mathbf{1 6 : 1}}$ & 0.3 & 0.1 \\
$\mathbf{C}_{\mathbf{1 7 : 0}}$ & 0.2 & 0.2 \\
$\mathbf{C}_{\mathbf{1 8 : 0}}$ & 33.6 & 32.9 \\
$\mathbf{C}_{\mathbf{1 8 : 1}}$ & 34.9 & 42.2 \\
$\mathbf{C}_{\mathbf{1 8 : 2}}$ & 2.9 & 3.5 \\
$\mathbf{C}_{\mathbf{1 8 : 3}}$ & - & 0.1 \\
$\mathbf{C}_{\mathbf{1 8 : 3}}$ & - & 0.2 \\
$\mathbf{C}_{\mathbf{2 0 : 0}}$ & 1.0 & 9.8 \\
$\mathbf{C}_{\mathbf{2 2 : 0}}$ & - & 3.2 \\
\hline
\end{tabular}

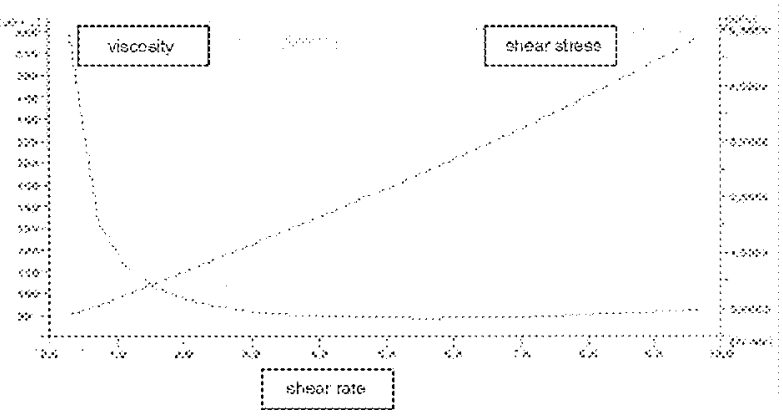

Figure 1

Flow curves of cocoa butter (viscosity $x$ shear rate and shear stress $x$ shear rate)

viscosity are of importance. The rheological properties of a fat depend on the temperature of storage, any pasteurization, cooling rate after pasteurization, and processing. 
Oils are normally Newtonian but at very high shear rates there may be a curvature towards the shear rate axis in the shear stress $x$ shear rate diagram, referred to as pseudoplasticity. It may be due to the alignment of the unit cells at high shear stresses which would cause a decrease in internal friction (Müller, 1973).

The importance of the microstructural level of structural organization becomes apparent when one examines the different levels of structure in a fat network in the context of how these levels of structure are responsible for the values of macroscopic physical measurements performed on the network. The levels of structure in a typical fat network are defined as the fat crystallizes from the melt.

Generally, $\beta$ ' crystals should lead to higher viscosity than $\beta$ crystals given their smaller size and higher surface area, and should also lead to increased particle interactions and potentially increased interfacial viscosity in emulsions, for example (Rosseau, 2000).

Many types of foodstuff, although showing the Newtonian linear relationship of $\pi / \gamma$ ( $\tau=$ shear stress; $\gamma=$ shear rate), exhibit a yield stress $\tau_{\circ}$ and are said to show plastic behavior.

The best models were chosen on the basis of the statistical parameter (determination coefficient - $R^{2}$ ) which measures the ratio of the total variation of the explained average of the regression. The smaller the value of $R^{2}$, the greater the distance of the experimental points to model. The best model is one with values which are near 1 . All the values of Table III showed values of $R^{2}$ higher than 0,9.

The variance analisis by Tukey HSD, at $5 \%$ of significance, was elaborated to verify the difference

Table III

Rheological parameters of different models

\begin{tabular}{|c|c|c|c|c|c|c|c|}
\hline & & & & MIXTURES & & & \\
\hline $\begin{array}{l}\text { RHEOLOGICAL } \\
\text { MODEL }\end{array}$ & M1 & M2 & M3 & M4 & M5 & M6 & M7 \\
\hline $\begin{array}{l}\text { Newton } \\
\eta(\text { Pa.s) } \\
\quad \tau=\mu \cdot \gamma\end{array}$ & $\begin{array}{l}\mathrm{a} \\
0.0473 \pm 0.0029\end{array}$ & $\begin{array}{l}\mathrm{a} \\
0.0484 \pm 0.0034\end{array}$ & $\begin{array}{l}\mathrm{a} \\
0.0503 \pm 0.0043\end{array}$ & $\begin{array}{l}\text { a } \\
0.0551 \pm 0.0008\end{array}$ & $\begin{array}{l}\text { a } \\
0.0510 \pm 0.0070\end{array}$ & $\begin{array}{l}\mathrm{a} \\
0.0518 \pm 0.0019\end{array}$ & $\begin{array}{l}\mathrm{a} \\
0.0374 \pm 0.0001\end{array}$ \\
\hline $\begin{array}{l}\text { Ostwald } \\
\left.\text { k (Pa.s }{ }^{\mathrm{n}}\right) \\
\mathbf{n} \\
\quad \tau=\mathrm{k} .(\gamma)^{\mathrm{n}}\end{array}$ & $\begin{array}{l}\mathrm{a} \\
0.1247 \pm 0.0440 \\
\mathrm{a} \\
0.8194 \pm 0.0019\end{array}$ & $\begin{array}{l}\mathrm{a} \\
0.1214 \pm 0.0410 \\
\mathrm{a} \\
0.8307 \pm 0.0707\end{array}$ & $\begin{array}{l}\mathrm{a} \\
0.2920 \pm 0.2529 \\
\mathrm{a} \\
0.8502 \pm 0.0910\end{array}$ & $\begin{array}{l}\mathrm{a} \\
0.1637 \pm 0.0103 \\
\mathrm{a} \\
0.7814 \pm 0.0113\end{array}$ & $\begin{array}{l}\mathrm{a} \\
0.1349 \pm 0.0570 \\
\mathrm{a} \\
0.8330 \pm 0.0884\end{array}$ & $\begin{array}{l}\mathrm{a} \\
0.1348 \pm 0.0537 \\
\mathrm{a} \\
0.8368 \pm 0.3375\end{array}$ & $\begin{array}{l}\mathrm{a} \\
0.0466 \pm 0.0024 \\
\mathrm{a} \\
0.9599 \pm 0.0087\end{array}$ \\
\hline $\begin{array}{l}\text { Bingham } \\
\tau(\mathbf{P a}) \\
\eta(\mathbf{P a} . \mathbf{s}) \\
\quad \tau=\eta \cdot \gamma+\tau_{0}\end{array}$ & $\begin{array}{l}\mathrm{a} \\
0.2550 \pm 0.0440 \\
\mathrm{a} \\
0.0416 \pm 0.0019\end{array}$ & $\begin{array}{l}\text { a } \\
0.3073 \pm 0.0221 \\
\text { a,b } \\
0.0422 \pm 0.0002\end{array}$ & $\begin{array}{l}\text { a } \\
0.3743 \pm 0.0570 \\
\text { b,c } \\
0.0442 \pm 0.0004\end{array}$ & $\begin{array}{l}\mathrm{a} \\
0.4510 \pm 0.0817 \\
\mathrm{c}, \mathrm{d} \\
0.0456 \pm 0.0002\end{array}$ & $\begin{array}{l}\text { a } \\
0.4847 \pm 0.2139 \\
\text { c,d,e } \\
0.0462 \pm 0.0003\end{array}$ & $\begin{array}{l}\mathrm{a} \\
0.4607 \pm 0.0240 \\
\mathrm{e} \\
0.0480 \pm 0.0001\end{array}$ & $\begin{array}{l}\text { a } \\
0.4607 \pm 0.0470 \\
\text { f } \\
0.0327 \pm 0.0002\end{array}$ \\
\hline $\begin{array}{l}\text { Casson } \\
\tau(\mathbf{P a}) \\
\eta(\mathbf{P a} . \mathbf{s}) \\
\tau^{0.5}=\left(\tau_{0}\right)^{0.5}+\mathrm{k}^{1}(\gamma)^{0.5}\end{array}$ & $\begin{array}{l}\mathrm{a} \\
0.0469 \pm 0.0224 \\
\mathrm{a} \\
0.0378 \pm 0.0289\end{array}$ & $\begin{array}{l}\mathrm{a} \\
0.0787 \pm 0.0043 \\
\mathrm{a} \\
0.0383 \pm 0.0017\end{array}$ & $\begin{array}{l}\mathrm{a} \\
0.0530 \pm 0.0376 \\
\mathrm{a} \\
0.0406 \pm 0.0018\end{array}$ & $\begin{array}{l}\mathrm{a} \\
0.0865 \pm 0.0122 \\
\mathrm{a} \\
0.0403 \pm 0.0005\end{array}$ & $\begin{array}{l}\mathrm{a} \\
0.0692 \pm 0.0445 \\
\mathrm{a} \\
0.0420 \pm 0.0018\end{array}$ & $\begin{array}{l}\mathrm{a} \\
0.0672 \pm 0.0523 \\
\mathrm{a} \\
0.0438 \pm 0.0018\end{array}$ & $\begin{array}{l}\mathrm{a} \\
0.0366 \pm 0.0061 \\
\mathrm{a} \\
0.0319 \pm 0.0004\end{array}$ \\
\hline
\end{tabular}

where:

$\eta=$ apparent viscosity

$\mathbf{k}=$ consistency index

$\mathbf{n}=$ flow behaviour index

$\tau=$ shear stress

$\tau_{\mathbf{0}}=$ yield stress

$\gamma=$ shear rate 
between samples at the same rheological model parameter. The statistical difference was observed only to Bingham viscosity. The values of the viscosity of the Newton, Ostwald and Casson models showed small differences (Table III).

All flow behavior index $(n)$ values are smaller than 1 , thinning occured, so the fats analized showed pseudoplasticity.

As the stress is increased the flow behavior usually changes into a power-law dependence of steady-state shear rate on shear stress. For structured liquids, this behavior generally gives way to Newtonian behavior at the highest stresses. For structured liquids this transition from very high (creep) viscosity $\left(10^{6}\right.$ Pa.s) to mobile liquid $(0.1$ Pa.s) can often take place over a single order of magnitude of stress. This extreme behavior, when viewed on a linear basis, gave every reason for believing that the material had a yield stress, and in many cases the flow curve seemed to be adequately described by Bingham's simple straight-line-withintercept equation. However, if viewed on a logarithmic basis, the equally simple Newtonian/power-law/ Newtonian description is clearly seen (Barnes, 1999).

The macroscopic rheological properties of the fat network are influenced by all levels of structure defined during the formation of the network, i.e. the structure of the individual triacylglycerols, the structure of the individual crystalline units formed, or the polymorphic nature of the network, and the microstructural level of structure (Narine \& Marangoni, 1999).

The bigger the molecule of an oil, the higher its viscosity. Palmitic acid with sixteen carbon atoms has a lower viscosity than stearic acid which has eighteen. All oils have a fairly high viscosity because of their long chain structure. The longer the chain of the fatty acids, the higher the viscosity. The viscosity also increases with saturation of the carbon-carbon double bonds. The greater the molecular interaction, the greater the viscosity (Müller, 1973). Cocoa butter has a lower viscosity and consistency index than cupuassu fat, which is explained by the triacylglycerol composition.

The flow curves (viscosity $x$ shear rate and shear stress $x$ shear rate) from Rheotest of cocoa butter and cupuassu fat are shown in Figures 1 and 2.

\section{Microscopy}

Crystalization at $25^{\circ} \mathrm{C}$ of the cocoa butter and the cupuassu fat was viewed under a microscope, at 40X magnification. Images were recorded using a digital video camera mounted to the microscope, and then viewed and analyzed through the computer program IMAGE PRO PLUS (Figures 3 and 4).

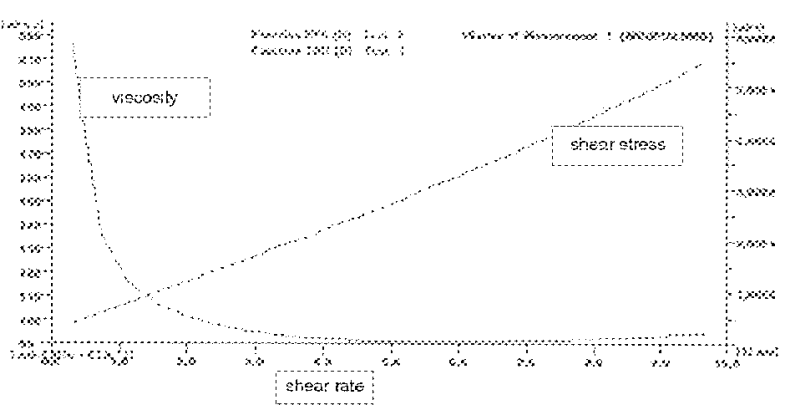

Figure 2

Flow curves of cupuassu fat (viscosity $x$ shear rate and shear stress $x$ shear rate)

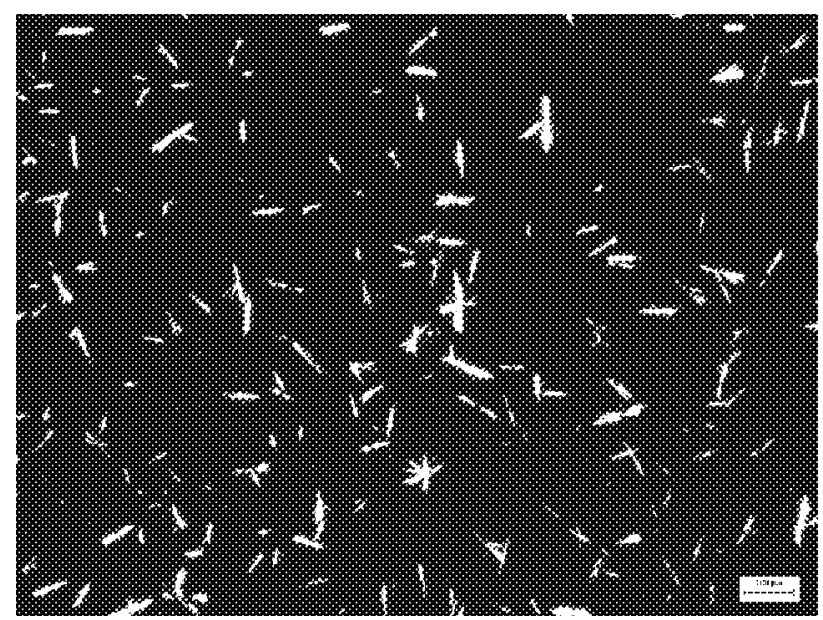

Figure 3

Cocoa butter crystals at $25^{\circ} \mathrm{C}(40 \mathrm{X})$. The bar represents $100 \mu \mathrm{m}$.

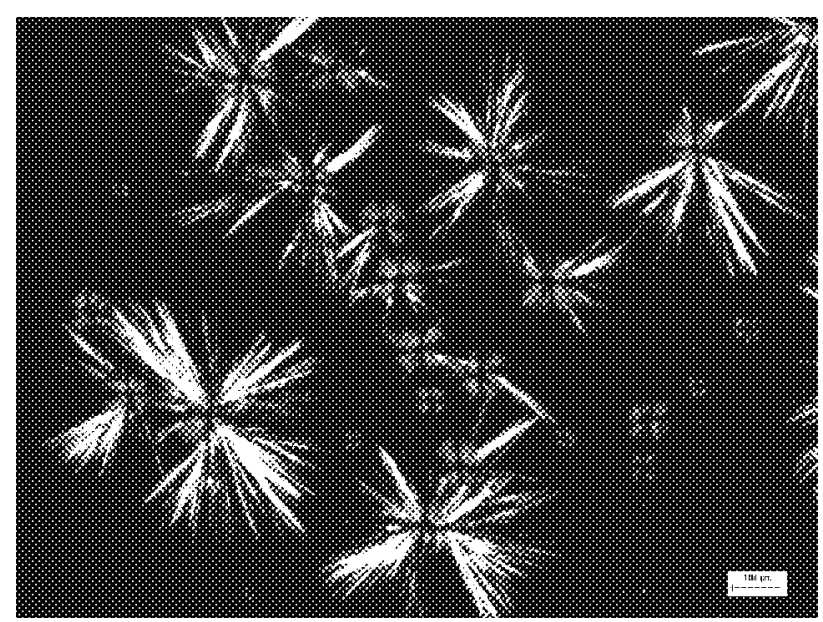

Figure 4

Cupuassu crystals at $25^{\circ} \mathrm{C}(40 \mathrm{X})$ The bar represents $100 \mu \mathrm{m}$. 
The microscope is a very useful tool in making such a study, especially when used with polarized light which increases our ability to see crystal structures. If we cause cocoa butter to crystalize on the stage of the microscope, quietly without agitation, and observe the action with the benefit of polarized light we may observe the following sequence of events: Before any crystals have appeared the field is blank. The first visible sign of crystal formation is seen when a few tiny, needle shaped crystals appear scattered throughout the field. Instead of an orderly increase in the number of such crystals in new locations in the field, we next observe the formation of additional crystals apparently superimposed on the original crystals with their axes crossed and from then on this type of crystal growth proceeds faster than does the formation of new single crystals. Eventually, a bundle of the needles is formed around each original, single crystal and growth continues until the bundles join up to form a solid mass.

Proper crystalization of the fat on the enrobed piece is important to finished product quality. The main requirement is that the surface be glossy, with the desired shade of brown.

The fats and lipids present in natural resources are mixtures of different types of triacylglycerols. Therefore, complicated behavior of melting, crystalization and transformation, crystal morphology and aggregation of the real-fat systems are partly due to the physical properties of the component triacylglycerols, and partly due to the phase behavior of the mixtures. In general, three typical phases may occur in binary solid mixtures, when the two components are miscible in all proportions in a liquid state: solid solution phase, eutectic phase and compound formation (Sato, 2001; Timms, 1985).

In cocoa butter (Figure 3) small needles of stable -form were found (Vaeck, 1970). The length of the cocoa butter crystals (ß-form) was $48.19 \pm 22.83 \mathrm{~m}$.

The types of crystals observed in the cupuassu fat (Figure 4) were: central core or nucleus of tightly-packed, rather broad needles surrounded by radially-oriented, long, narrow, needle-like crystals (spherulites type A) (Gioielli et al., 2003), diameter of $461.13 \pm 90.30 \mathrm{~m}$; axial crossed crystals of the unstable -prime form (Kleinert, 1970), diameter of $83.31 \pm 31.91 \mathrm{~m}$.

Polymorphism was also observed in cupuassu fat. Differences were found between crystal formation of cupuassu and cocoa fat, also shown by the cooling curves of these fats (Lannes, 2003).

The triacylglycerol SOS (1,3-distearoyl, 2-oleoyl-sn-glycerol) in which $\mathrm{R} 1=\mathrm{R} 3=$ stearicacid, and $\mathrm{R} 2$ = oleic acid) is a triacylglycerol present in cocoa butter $(26,96 \%)$ and in cupuassu fat $(29,13 \%)$ as the main fat, and thereby one of the major confectionery fats (Lannes, 2003; Metin \& Hartel, 1998; Sato, 2001). SOS has five polymorphs, $\alpha$ (melting point $\left.=\mathrm{MP}=23.5^{\circ} \mathrm{C}\right), \quad \gamma \quad\left(\mathrm{MP}=35.4^{\circ} \mathrm{C}\right), \quad \beta^{\prime}$ $\left(\mathrm{MP}=36.5^{\circ} \mathrm{C}\right), \beta_{2}\left(\mathrm{MP}=41.0^{\circ} \mathrm{C}\right)$ and $\beta_{1}\left(\mathrm{MP}=43.0^{\circ} \mathrm{C}\right)$.

A study of the microscopical appearance and of the capillary melting points can only give qualitative information about the existence of different polymorphic forms. The melting point of cupuassu fat is higher than that of cocoa butter (Lannes et al., 2000).

Chocolate is a dispersion of a cocoa solid in a fat phase. So, the presence of fat crystals can either stabilize or destabilize emulsion droplets, depending on whether they are intraglobular or in the continuous phase. Present in the continuous phase, fat crystals may come into contact with the interface and adsorb on the surface of the droplet, thereby potentially stabilizing the dispersion. As part of the dispersed phase, lipids in a state of partial crystalization may substantially increase emulsion destabilization. During processing and/or storage, intraglobular fat (e.g. in cream) may solidify forming crystals that can protrude through the interface leading to droplet coalescence (Bricknell \& Hartel, 1998; Rosseau, 2000).

\section{CONCLUSIONS}

Generally, the rheology of fats is studied in a solid state and the results are shown as textural properties. In this work the behavior of two fats and their mixtures in liquid state were studied along with testing the rheological models. It was found that some models could be used to describe the behavior of those fats at $40^{\circ} \mathrm{C}$, at high stress. This or These results could helpful in the chocolate products industry, because the viscosity of these products depends on the fat phase and has a great importance in the process. Cupuassu fat has higher viscosity than cocoa butter.

The polymorphic form in cupuassu fat was also shown, in addition to the differences between the crystalization of cupuassu and cocoa fats.

\section{ACKNOWLEDGMENTS}

Our thanks to the FAPESP-Fundação de Amparo à Pesquisa do Estado de São Paulo.

\section{REFERENCES}

American Oil Chemists' Society. (1990). Official methods and recommended practices of the AOCS, (4th ed.) Champaign, II, USA.

Barnes, H.A., Hutton, J.F., Walters, F.R.S. An introduction to rheology. London: Elsevier, 1999. p.1-35

Bricknell, J. and Hartel, R.W. (1998). Relation of fat bloom in chocolate to polymorphic transition of cocoa butter -J. Am.Oil Chem. Soc. 75, 1609-1615.

Gioielli, L.A., Simões, I.S., Rodrigues, J.N. (2003) Crystal morphology and interactions of binary and ternary mixtures of hydrogenated fats. J. Food Eng., London, 57, p. 347-355. 
Hartman, L. \& Lago, R. C. A. (1973). Rapid preparation of fatty acid methyl esters from lipids. Lab. Pract, 22, 475-476, 494.

Kleinert, J. (1970). Studies on the formation of fat bloom and methods of delaying it. In- Twenty years of confectionery and chocolate progress, ed. C.D. Pratt; E. Vadetzsky; K.E. Langwill; K.E. McCloskey; H.W. Schuemann. AVI, Westport, pp. 175.

Lannes, S.C.S. (2003). Cupuassu-A new confectionery fat from Amazonia -- Inform-AOCS. 14, 40-41.

Lannes, S.C.S. \& Gioielli, L.A.(1997). Misturas entre manteiga de cacau e sucedâneos comerciais: estudo de diagramas de curvas iso-sólidas e de iso-consistência - Rev. Soc.Bras.Ciência e Tec. Alim. $15,132-7$

Lannes, S.C.S., Medeiros, M.L., Gioielli, L.A. (2000) Interações físicas entre gorduras de cupuaçu e de cacau. In: XVII CONGRESSO BRASILEIRO DE CIÉNCIA E TECNOLOGIA DE ALIMENTOS. Proceedings. SBCTA, 2, 6.150.

Lipp, M. and Anklam, E. (1998). Review of cocoa butter and alternative fats for use in chocolate -- Part A. Compositional data. - Food Chem. 62, 73-97.

Lipp, M. and Anklam, E. (1998). Review of cocoa butter and alternative fats for use in chocolate -- Part B. Analytical approaches for identification and determination - Food Chem.62, 99-108.

Metin, S. and Hartel, R.W. (1998). Thermal analysis of isothermal crystallization kinetics in blends of cocoa butter with milk fat or milk fat fractions - J.Am.Oil Chem.Soc. 75, 1617-1624.
Muller, H.G. Introduccion a la reologia de los alimentos. Zaragoza: Acribia, 1973. 174p.

Narine, S.S., Marangoni, A.G. (1999). Microscopic and rheological studies of fat crystal networks - J. Crystal Growth, 198/199, 1315-1319.

Narine, S.S. \& Marangoni, A.G. (1999). Relating structure of fat crystal networks to mechanical properties: a review - Food Res. Int. 32, 227-248.

Rosseau, D. (2000). Fat crystals and emulsion stability -- a review - Food Res. Int. 33, 3-14.

Rohm, H. \& Weidinger, K.H. (1993). Rheological behaviour of butter at small deformation - J.Texture Stud. 24, $157-172$.

Sato, K. (2001). Crystallization behaviour of fats and lipidsa review - Chem. Eng. Sci. 56, 2255-2265.

Timms, R.E. (1985). - Physical properties of oils and mixtures of oils - J.Am. Oil Chem. Soc. 62, 241-249.

Vaeck, S.V. - Cacao butter and fat bloom. In: PRATT, C.D. VADETZSKY, E., LANGWILL, K.E., McCLOSKEY, K.E., SCHUEMANN, H.W., eds. - Twenty years of confectionery and chocolate progress. Westport: AVI, 1970. p.123-155.

Vasconcelos, M.N.L. et. al.(1975). - Estudo químico das sementes do cupuaçu - Acta Amazônica 3, 293-5.

Venturieri, G.A. (1993). - Cupuaçu: a espécie, sua cultura, usos e processamento - Clube do cupu, 108. 